\title{
Peertechz
}

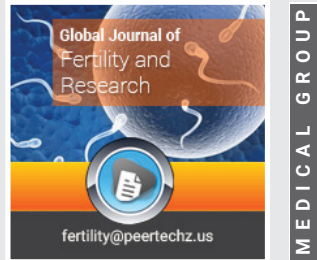

\section{Surrogacy in National VS International Countries}

Received: 22 March, 2021

Accepted: 15 May, 2021

Published: 20 May, 2021

*Corresponding author: Vipul Chaudhary, Manav Rachna University, University in Faridabad, Haryana, Tel: 9718448284; E-mail: vipulchaudhary218@gmail.com

https://www.peertechzpublications.com

\section{Vipul Chaudhary*}

Check for updates

\section{Abstract \\ This article talks about the practice of surrogacy between national and international countries and also provides relationship that how far countries are developed in the commissioning of surrogacy. Additionally, this article also discusses about the cases with regard to practice of surrogacy in different countries along with exceptions.}

\section{A. Australia}

\section{Introduction}

Surrogacy is commissioned in Australia based on the laws and regulations that their states and other union territories obey. The sources do not provide a complete understanding of how many states and their respective territories are involved in surrogacy ${ }^{1}$. In Australia, their main goal is to empower and improve only altruistic surrogacy, as this is the most common type of surrogacy in the world, and there is no trafficking of body parts in this form of surrogacy. That is why, in comparison to industrial surrogacy, altruistic surrogacy is more commonly used. In the case of altruistic surrogacy, Australia had already imposed rational restrictions, such as a fair remuneration for the surrogate mother in exchange for her motherly services. To determine the benefits and drawbacks of these two types of surrogacies, such as altruistic and commercial surrogacy, we must first distinguish each of these kinds, then compare what is permissible in altruistic surrogacy with what is not permissible in commercial surrogacy, and only then can we arrive at a solution. In altruistic surrogacy, only a reasonable sum is transferred to the surrogate mother to assist her in meeting her financial needs, while in commercial surrogacy, most people attempt to persuade the surrogate mothers to help, and after a while, they become involved in the chain of human trafficking, including the surrogate babies. However, although

${ }^{1}$ The most closely related areas are adoption law and the law of reproductive technology, which are largely regulated by the territory and states and the laws of parental responsibility, immigration and citizenship, which are regulated nationally.
Australia's laws are strict and the country is classified as established, there are some areas where legislation is lacking.

\section{Domestic regulation of surrogacy}

a) Altruistic surrogacy: In Australia, their respective forces of clinics and data experts first assessed the conditions in their states and union territories, and when they determined that altruistic surrogacy was needed, the country made serious efforts to develop altruistic surrogacy and always considered the nation's growth in order to empower it. When the country decided to control altruistic surrogacy, everyone was focused on how the laws would benefit the institution and what the loopholes would be when doing so: First and foremost, if the intended parents believe they are fit to enter into such a form of surrogacy, they must ensure that they are capable of carrying out their parental responsibilities and that they are financially strong enough to support the child during his or her life. When the court is satisfied that the intended childless parents are in desperate need of a child and is certain that the intended parents are financially stable, the court will allow the surrogate mother to pass the surrogacy mother's authority. In addition, the court believes that the intended parents must compensate the surrogate mother for her suitable facilities that will assist her in meeting her basic needs in the future, and that money is also covered in terms of medical terms, and so on.

i. Parental guidelines: This argument is very important in surrogacy because it describes how parental responsibility is transferred from one parent to another. In order to do so, the intended parents must contact the court and apply for assistance, as well as have financial 
power. Only then can the court transfer parental authority from the surrogate mother to the intended parents. Thus, the expected parents must ensure that they will not, at any cost, discard any child from their lives, even if the child has a disability, and that they will treat the child with the utmost care and respect while the child is alive. Otherwise, the court will take appropriate measures in the child's favour ${ }^{2}$. This point of parental responsibility is extremely advantageous since it allows parents to welcome any child into their lives if they are financially capable of handling the child. This should be followed in all circumstances so that a child's whole life is filled with love and happiness.

Surrogacy is only used in Australia when the parents are having difficulty conceiving, and the surrogate child is often considered as the family's biological child. According to Australian surrogacy laws, the surrogate mother who cares for the infant for nine months in her womb is considered as the child's parent, even though she is not genetically related to the child ${ }^{3}$. If the surrogate mother and her companion who assisted the intended parents in achieving the pregnancy are treated as parents of that child, the surrogate mother and her companion are treated as parents of that child. And often the intended parents have to go through this period of their lives where they are not recognised as the biological parents of the surrogate child. And often the intended parents have to go through this period of their lives where they are not recognised as the biological parents of the surrogate child. To determine who will be the parents of that child, one thing is certain: legal formalities during the case, such as birth official records, must be duly completed, and the parents must demonstrate to the court that they are capable of handling custody of that child.

The intended parents must be competent to master the custody of their child before the surrogacy requirements are met, and these surrogacy conditions must fit the parental responsibility, otherwise the parental responsibility will be abused. In a variety of situations, in certain parts of Australia, the court determines if the child's wishes will be met in accordance with his or her needs. In other parts of Australia, there are specific regulatory bodies that assist in the management of surrogacy. In certain parts of Australia, the court determines if the child's wishes will be met in accordance with his or her needs. In other parts of Australia, there are specific regulatory bodies that assist in the management of surrogacy ${ }^{4}$. Surrogate mothers in other parts of Australia should remind themselves that their fair medical costs are already protected under surrogacy legislation.

${ }^{2}$ Parentage Act (2004) (ACT), s 29 Surrogacy Act 2010 (NSW) , S 39; Surrogacy Act 2010 (Qld), s 39(2); Family Relationships Act 1975, Family Law Regulations 1894.

${ }^{3}$ In the published surrogacy cases, the intended father was the genetic father. In Milkbanks's study, the intended father was the genetic father in 47 of 69 cases.

${ }^{4}$ Status of children Act 1974 (Vic), s 22(1);Surrogacy Act 2008 (WA),ss 1922. ii. Surrogacy protocol establishment: The beginning of surrogacy is not adequately supervised in certain cases, according to Australian law. The main goal of this section is to concentrate on the surrogate mother's actual fees in exchange for her services to the intended parents. According to court rulings, it is mandatory in most parts of Australia to offer the best possible assistance to the surrogate mother by covering her medical expenses during the surrogacy phase ${ }^{5}$. In other Australian states, the surrogate mother must inform her surrogate mother of her fair medical costs, which are already protected by surrogacy legislation.

If we consider the case of Tasmania, surrogacy legislation only addresses the treatment of the surrogate child after birth, parental authority, and one of the most relevant issues to be addressed, which is the surrogate mother's suitable expenses, except insurance coverage, which would be paid only by the intended parents. It is the responsibility of health centres to cover the surrogate mother's and baby's fair expenses, and if these expenses are not covered, it is the responsibility of health centres to inform surrogate mothers that insurance coverage would also assist them in satisfying their wishes.

b) Surrogacy matters: Parenting instructions and adoption: This parental obligation is very important in the lives of surrogate and other children who are born through natural birth, surrogacy, or adoption. Intended parents, especially in some parts of Australia, such as Queensland, should be aware of the laws and know how to manage the child's responsibility, which includes his schooling, food, and clothing needs. These two factors, such as parental obligation and adoption, play an important role in the surrogacy process. Parental responsibility must be adequately handled in order to take on the family from a surrogacy standpoint and in real life; otherwise, it is pointless to handle child custody according to family law. These issues of parental responsibility, as well as other issues like matrimonial disputes and child custody, are resolved in family courts. Parents should observe the criteria set out by the states and union territories when accepting children into their lives by natural birth, surrogacy, or adoption. Guidelines cannot be kept in the minds of parents; they must take suitable action for the child's safety ${ }^{6}$.

Some planned parents are capable of handling the child's custody, according to adoption law. Only when both the parents and the child engage with each other will this obligation be fulfilled. Mutual understanding between children and their parents is essential, and only when parents understand child psychology only then they can welcome any child into their lives. Only if the intended parents and surrogate have a common understanding would the surrogate child consider the intended parents as their biological parents. Alternatively, if one of the planned parents already has a child and the other

\footnotetext{
${ }^{5}$ Surrogacy Act 2010 (Australia).
}

${ }^{6}$ Family Law Act 1975 (Cth), s65C permits any 'person concerned with the care , welfare and development of the child' to apply for a parenting order 
wishes to adopt another child, both parents must have a shared relationship in order to accept the adopted child 7 .

When we combine adoption and parental responsibility, each law operates in these areas separately depending on the surrogacy organization. Each court has the authority to deal with issues concerning parental responsibility, but courts cannot invade someone's home to determine whether or not the parents are properly caring for their children. The courts have no power to change the lives of parents, but they can intervene in surrogacy laws.

\section{B. France}

\section{Introduction}

In France, the French Court de Cessation was regarded as the ultimate governing authority, and the French regulations deemed this court suitable for dealing with domestic matters, with only this court having the authority to oversee the surrogacy process between French couples. When this court issues a surrogacy law, everybody must obey it as directed, and no one is allowed to disregard the French Court's decision. When this court makes a decision on the institution of surrogacy in a foreign country, even though it differs from the rules for surrogacy arrangements, the general public must follow the judgement of the French Court. The French legal system is extremely rigid and swift, and no one can challenge a court's decision. It was thought that if a surrogate mother from France or another couple from another country carried out the surrogacy, the French government would oversee the process $^{8}$. When we look at the actual hand, though, it is very tangled. According to France's awareness, 150-200 children are born abroad each year, implying that France is working to help intended couples and surrogate mothers, as well as work for the child's and surrogates' welfare, though the laws are strict in some cases.

If a couple enters into a surrogacy agreement in France, they must demonstrate their full personality, skills, and follow all French laws. First and foremost, in order to enter into surrogacy, one must be acquainted with the surrogacy protocol, whether the party is the surrogate or the intended parents; second, after all of these formalities are completed, the parental obligation, registration process, and all paperwork must be completed according to French country guidelines.

\section{Domestic cases}

While the practice of surrogacy are invalid as per civil regulation, therefore in criminal law the regulation of surrogacy is also not practiced and permitted.

\section{a) Surrogacy arrangements in civil law}

It was specifically mentioned in the French Code of

${ }^{7}$ In Re Michael (surrogacy arrangements) (2009.)

${ }^{8}$ Cour de cessation, civile, Chambre civile 1,6 avril 2011., La gestation pour autrui devant la Cour de Cessation', Dalloz 2011.1064.
Civil Regulation, which is covered in Article (7-16), that: 'No procedure related to surrogacy related to child delivery or any service from the surrogate side for a third party will be supervised because it is considered improper when it is performed for a third party according to the Civil Code of French.' This means that surrogacy in France is limited to their home nation, and only in such cases does this country allow surrogacy to take place in another country with the assistance of France; otherwise, such surrogacy agreements are not considered true.

In 1994, the French Civil Code enshrined this point of nullity and void. If we consider other parts of France, this situation is a waste of time because it is a matter of reproduction and providing a good life for needy couples. If the nullity rate continues to rise, there will be fewer surrogate babies in the French Nation. This act of reproduction entails not only the exchanging of goods and services, but also the fusion of two bodies with the assistance of two parties, resulting in the birth of a child. Every individual must respect the dignity of the human body, which is created by God. There are also several people who are born with a variety of mental illnesses but live their lives to the fullest. Due to the issue of surrogacy, this Act was known to the French Court before the French Court. The French Court of Cessation said that such surrogacy, even though it is altruistic, devalues the public's ideals because when a woman brings an infant into her body and visualizes the picture of that child in her mind, she is involving not only her body but also her mental thought, which alters the public's opinion. It is a shame that France, as a powerful nation, is still debating whether or not to allow altruistic surrogacy. In certain parts of the world, this occurs.

The first policy of the French Court de Cessation was to remind the general public that the human body cannot be used for entering into agreements. The court expresses that the body is not a commodity that can be used to help anyone else, and the French court focuses on excluding the use of the body from agreements. The French Court also advises surrogates not to enter into private contracts or deals involving the lives of surrogate children. The Court decided to send a message to the public that while some families are in desperate need of an infant, other times these intended parents are in the first place to throw those children into the garbage of human trafficking or slavery, where not only babies but even surrogates are involved, and they are unable to escape.

The French Court made a declaration in the second general policy, which was also relevant to the welfare of people, that the lawful status should not be subjected to private contracts. This concept is also very critical because it aids in and plays a significant role in protecting people's lives and dignity. Human bodies and their respect are not limited to themselves in France, but the country has taken special care of them in order to prevent the misappropriation and abuse of human bodies. The Ruler of the French Court, Francois, devised a scheme in which everyone can complete the documentation related to birth in order to secure individual rights, and it is obligatory to register on the child's records during the birth process; otherwise, 
action may be taken against such public. The United Nations Convention on the Rights of the Child is completed and covered in the United Nations Convention on the Rights of the Child (UNCRC) ${ }^{9}$. The French Court stated that the registration process is very important for every citizen because it aids in identifying each citizen's residence and the location of any operation. It assists the government in maintaining people's official documents such as marriage, divorce, childbirth, property leasing, rental wombs, and any surrogacy procedure. These types of practices should be implemented in official locations so that stakeholders can be recognized in the event of a dispute. These records are kept by individual branch officers who must have civil rank in their field to keep them. Their job is to collect as much information as possible on any practice that has taken place, such as the birth of a child, and to record the child's names so that the surrogate mother may be identified by the child's name, but this information should be kept confidential with civil rank officers. The French Civil Code (Article 25-311) contains this provision. When the 1991 verdict became known to the general public, Parliament established, under Bioethics law, that anybody attempting to hide the identity of a surrogate mother, surrogate infant, or any intended parents must be dealt with iron hands immediately, as it is a very confidential matter and also in the best interests of the child.

\section{b) Surrogacy managements are prohibited in crimina} law $^{10}$

While the conduct of surrogacy is not governed by private agreements or the French civil code, the conduct of surrogacy in the civil code criminal law is intended to either conduct or ban surrogacy treatments. At the time, the French Penal Code did not, first and foremost, share any views on the legalization of surrogacy in France. As a result, under criminal law, the management of surrogacy prohibition is protected by Article 13-227, which encourages the birth process while punishing those who want to conceal their true identity. If intended parents or surrogate mothers fail to participate in the registration process, it may lead to unlawful abuse of the child and his or her body. If we look at existing penalties, a surrogate mother may face a sentence of up to three years in prison and a fine of up to 45,000 euros.

From 1991 to 1994, the French Court defined certain clauses and penalties for specific departments, such as agencies, physicians, and health care centers, which can be seen in the Bioethics of France. Article 12-227 states that someone who tries to behave double-handed in surrogacy matters between a person or a couple who promotes an infant as an advertisement and a surrogate who agrees to bear the child for a fee is guilty of a felony. For the first instance, the court punishes the offender with a sentence of one year or more in prison and a fine of up to 15,000 Euro, which can be doubled on

${ }^{9}$ Adopted by the General Assembly of the United Nations on 20 November 1989, See in particular Art 7(1).

${ }^{10}$ Family Law Act 1975 (Cth), s65C permits any 'person concerned with the care , welfare and development of the child' to apply for a parenting order the second and subsequent occurrences of behavior. Hospitals or organizations are also subject to fines of up to 450,000 euros under this French provision if they have any knowledge of the truth, which is protected by Article 13-227.

\section{International cases}

Only altruistic surrogacy is allowed in France, and surrogacy is prohibited in all other nations, according to French law. If we look at foreign matters in terms of the French country, we can see that only French citizens are permitted to engage in domestic or international affairs. In international matters, it is critical to decide how parental responsibility will be distributed to French citizens and other overseas citizens, because parental responsibility must be handled at the outset because international matters include cross-border surrogacy, which will be supervised by French officials.

\section{a) Management of foreign civil position documents}

In France, there is a strict regulation that all documents passed by French officials or authorities must be identified in order to determine parental responsibility carefully, and this responsibility cannot be controlled by the general population of France and other citizens from other countries. In most cases, there is no need to exert effort; instead, concentrate on the papers. This clause in the contract is used to determine the true identity (Article 47 of the Civil Code) ${ }^{11}$. Records imposed by civil officials or civil authorities as per the French Regulation should be presented between the surrogate child and the intended parents in the management of surrogacy, and every child has the right to know about his or her past. Article 47 mentions this provision. There are separate bodies that look into the issues surrounding the institution of surrogacy in a foreign country, and one of these bodies, the Council d'état, has supremacy in the nation when it comes to surrogacy issues. These departments look at issues such as the ethnicity of citizens who are all from different nations, as well as the duties of surrogate mothers in the opinion of the French people.

No one may intervene with the exercise of functions by the Council d'état, and any decision made by this body is considered final and necessary. A case was brought before the Council of State in which a French father engaged in the practice of surrogacy in India. In this case, an Indian legal mother went through a surrogacy process and gave the baby to a French man, but the French embassy in India refused to hand over custody of the child to the French father because it was not done according to French regulations and also failed to hand over travel documents, the French father decided to settle in India, but India was not ready to accept him because he did not belong to an Indian country and did not have Indian citizenship; otherwise, India might have been willing to accept such a person. Later, the French parent took his case

\footnotetext{
${ }^{11}$ Such a truthful foreign record may be the basis for applying conflict of law rules (e.g. marriage, maintenance, parental responsibility) or for its enforcement (e.g. divorce), depending on the legal nature of the document issued.
} 
to the Council of State, but that division also asked a series of questions, leaving the surrogate child stateless and without a parent ${ }^{12}$.

When these issues were asked in the case, no one could contest them because it was a passport and child custody problem. After some time, the entity, the Council d'état, gave the French father a chance to speak with them about travel documents, and the Council d'état decided to consider a twoway theory. The first hypothesis was covered in Article 47 of the Civil Code, in which the body focused on the birth records of the surrogate child who was born in India via surrogacy and gave a chance to prove whether the child was delivered legitimately or not, and the French body also conducted DNA tests on the father and surrogate child. After going through all of the tests, the French body Council d'état was pleased that the French father was not guilty and had all of the required travel documentation when he came to this Hon'ble Body, and after the DNA examination, the French body simply adjourned the case in favor of the French parent and surrogate kid.

\section{India}

\section{Introduction}

Trading genetic pool banks of India were founded after a lot of investigation and analysis in various fields such as law, and such pool banks were made in order to provide support to the needy couple. Later, a range of outsourcing industries were established, which were in demand not only nationally but also internationally. The majority of the people were from other nations, including Afghanistan, Indonesia, the United Arab Emirates, Malaysia, Pakistan, and Uzbekistan, as well as Indian citizens from Canada, the United States, and the United Kingdom. However, when it came to sperm banks and invitro fertilization (IVF) clinics, Nepal did not do well in India. The majority of Indian people needed South Asian genetic and genuine qualities in great sperm contributors. Rental wombs are another viable option in India, and they are not prohibitively costly. If we compare India to other countries on a global scale, no one can match India's reliable and low-cost medical facilities, easy access to substitute wombs, or even the number of contributors. That is why most people were drawn to its services because certain chap services and benefits of rental wombs and medical services were unavailable anywhere else in the world, and these engagements were strictly controlled by Indian law. Finding surrogates or genetic banks for foreign people and non-resident Indians is not difficult in India because the country consistently outperforms the rest of the world in most fields ${ }^{13}$.

When India began to develop slowly but steadily, it quietly became one of the most favourable and acceptable destinations in the world for the fertility industry, and reproductive tourism became a regular occurrence. If we look at the charges in the United States, they are about Rs. 25,000 crores today (US

\footnotetext{
${ }^{12}$ Decree No 2004-1543 of December 2004.

${ }^{13}$ Available at qz.com
}

DOLLARS 5,000 million). Since 1978, modern technologies such as ART Technologies have been in high demand in India, and the number of surrogate industries is at an all-time high when compared to the global average. There have been a number of industries in India that we can't even imagine, such as in-vitro fertilization centers, surrogacy clinics, and artificial insemination industries.

While commercial surrogacy was established to benefit women, the majority of those involved were involved in the trade of bodily services. That is why altruistic surrogacy is legal in every country on the planet. While there was no law to regulate commercial surrogacy, most people thought of it as a company. However, the Indian government sought to deal with it with iron hands because commercial surrogacy allows people to manipulate surrogates and their infants. In order to avoid this, the Indian government chose to bring commercial surrogacy into the legal sphere.

Everyone was aware that commercial surrogacy will not be phased out anytime soon due to the lack of a surrogacy regulation rule. However, it is true that India lacks management. To combat this exploitation, the Indian government formed a Research Body known as the Indian Council of Medical Research (ICMR), which released Guidelines in 2005 to address illegal trafficking in the country as well as the devaluation of the country's reputation and new technologies such as Assisted Reproductive Technology (ART). These national guidelines for accreditation, supervision, and regulation, which are nonstatutory, have no legal purity, and are not mandatory, are in effect for the medical industry in India ${ }^{14}$. In India, most people try to steal money to help themselves, and because there is no management, no one will speak out against it. The value of the country is often declining due to certain citizens and a lack of provisions. There are a large number of surrogacy cases that are linked to mistreatment, human trafficking, extortion, and unethical crimes that can never be monitored, go unregistered, and surrogate mothers are also caught in the chain of exploitation as a result of the country's poverty. India is known for its low-cost medical facilities, whether it is abortion, surrogacy, or artificial insemination, and as a result, most residents from other countries flock to India. When it comes to surrogacy prices, the United States, with the exception of Australia and the United Kingdom, is at the top of the list. However, because of the low cost of surrogacy and classified advertising in newspapers, the US has made improvements in the surrogacy operation of about 10,000 US DOLLARS. In comparison to India, however, there are fewer egg donors and surrogate mothers in the United States. The surrogacy practiced in India is very trendy and conducted, on a massive scale because $2 / 3^{\text {rd }}$ population of India live below poverty line $\mathrm{e}^{15,16}$.

\footnotetext{
${ }^{14}$ National Guidelines for Accreditation, Supervision and Regulation of ART Clinics in India, 2005, S.3.1.

${ }^{15}$ Anees V Pillai, Surrogate Motherhood and the Law: International and National Perspectives 102-103 (Regal Publications, New Delhi).

${ }^{16}$ National Guidelines for Accreditation, Supervision and Regulation of ART Clinics in India, 2005, S. 3.2.3.
} 
As Louise Brown, the world's first test-tube infant, was born in the year 1978 in the United Kingdom, most celebrity babies were on the rise, and this trend continued across the globe. There are other ads in the global news about Angelina Jolie's or Kim Kardashian's adoptions, for example. India was also aware of this trend thanks to the well-known Indian film celebrity Sushmita Sen, who encourages all women to engage in the adoption, surrogacy, or IVF procedures without regard for old-fashioned traditions and taboos. Most of the kids from orphanage or NGOs are still in a need of parents but they are affected from some disability and sometimes they are born parentless $^{17}$.

Most of the overseas citizens and NRI would-be parents too are involved in process of surrogacy or adoption even without their interests. Infant adoption in India is not an easy job. It has been covered with long-layered lawful processes and knotty long-lasting formalities because it is a matter of concern with the life of the child and nobody even can't take risk incase of child otherwise the life of child will become hell. It is good that some of the citizens are taking a good initiative while adopting kids and providing them a suitable life filled with joys and happiness. Although our country has got independence and even our constitution has been still our country is lagging behind in terms of provisions related to adoption which applies to all the citizens who belong to Indian country irrespective of any caste, creed color, nationality or religion, even the Non-Resident Indians are also included in this list (NRIs), and lastly persons of Indian Origin (PIOs) or Overseas Citizens of India (OCIs). When some people cannot adopt any child after undergoing through this lengthy procedure then they can enter into the IVF health care centers or through the surrogacy. Therefore, India planned to take into consideration an appropriate regulation for those people who cannot adopt any infant due to the lengthy procedure or due to the absence of proper regulation for Indian as well as foreign citizens ${ }^{18}$.

\section{i. Adoption, ancestry and surrogacy- A maze or a problem}

The Custodians and Wards Act, was adopted in the year 1890 which enables the parents to adopt any kid irrespective of any religion, caste, race, sex as per the regulation of Custodian and Wards Act. Under this act parents can be simple turn into an infant's adoptive parents. Those parents who adopt such child under this act were regarded as "Custodians". In India there was a more noninterventionist Hindu Adoption and Preservation Act, 1956 which does not accept any parent other than Hindu adopt infant of Hindu community. This procedure is so lengthy and also covered with full of restrictions. As per Non-interventionist act any person other than Hindu or any foreign citizen can operate as custodian but were unable to hold the kids. But they can act as per the authority of guardianship but they cannot claim the authority of child completely ${ }^{19}$.

\footnotetext{
${ }^{17}$ Available at https://www.biography.com.

${ }^{18}$ Anil Malhotra and Ranjit Malhotra, Surrogacy in India: A Law in makingix (Universal Law Publishing co., New Delhi, India, 2013).

${ }^{9}$ Supra note 8 .
}

According to the Section 16 of Hindu Adoption and Preservation Act adoption documents play a very important responsibility when it comes to the completing of the formalities of adoption. But as per the act if any person such as Non-Resident Indian who had completed all the documents of an adoption deed from the foreign embassy in order to institute an immigration process of a child from Indian country, then also such person needs to undergo through sadness because the provisions of adoption is bit more complicated. As per the lawful provisions of the foreign country it is important first to institute such documents into the courts of custodian only then parentage authority is allotted to citizens as per the provisions of Hindu minority and preservation act which is concerned with the handling of the infant Still also after going through both of these acts and after filing the adoption deed still the parental liability does not facilitate. A paradox in regulation. It is stated that legitimate adoption as per the requirements of Hindu Adoption and Preservation Act is not at all successful for the conduct of immigration it would be conducted only on the one condition that protection clause should always be there as per the provisions of the Protection and Wards Act or Hindu Minority and Custody Act. Although it is completely different, but still need to follow or else not to follow.

ii. Surrogacy: Imported from india require for a regulation law

Surrogacy came into knowledge with the help of glamour industry and what this industry shows it becomes a trend. There was an international celebrity such as Elton John who was a renowned British personality and his Canadian film producer David Furnish became parents of an infant boy with the help of surrogacy arrangement in born to a substitute mother who was from New York and there are some other celebrities from the Indian film industry such as Shahrukh Khan and Amir Khan who also attained baby through surrogacy with the help of IVF. Nowadays, the reproductive tourism industry is on an emerging scale and everybody is becoming parents while using this platform and when it comes in cost in India it is around Rupees 25,000 which is equal to 5000 million US DOLLAR with the help of 1,00,000 health care centers related to IVF and also promoting surrogates, wombs and eggs etc. The cost of surrogacy in Europe is around 10,000 DOLLARS of the entire package which was also followed in the US but if we see in India it costs around 10,000 DOLLARS which means a huge difference although India is not a developed nation but the service which is provided in Indian industry is very beneficial as compared to the US and Europe. Unexpectedly, the number of surrogates is so huge as compared to any other country in terms of human Transplantation of Human Organs Act, which came into force in the year 1994 which was not in favor of commercial purpose such as sale and purchase of Human organs, lending of organs and any kind of commercial deal related to organs of the human body. Therefore, if we compare number of surrogates then India is on first number which mostly involve in surrogacy arrangements and these arrangements are applicable to separated parents, gay or unmarried partners, despite of the fact India does not go to tolerate same sex relationships. This concept of attaining a biological infant from someone's body 
with the help of technology and in return compensating for such service to the surrogate is very glowing in the reproductive industry of India ${ }^{20}$.

\section{An anomalous rule}

In mostly of the powerful nations such as US or Australia there is no need to enter into the practice of surrogacy or any contract concerned with the same. In major parts of the United Kingdom, these arrangements or practice or any contract associated with commercial surrogacy is completely unacceptable as per their regulation in order to stop and eliminate the exploitation against the use of Human Beings Organs. In some parts of Australia like in Queensland and Tasmania, engagement of any commercial surrogacy is a serious punishable offence and their punishments are very regrouping order to stop the ill-treatment against the use of Body parts used in the surrogacy arrangements such as human embryos or gametes etc. If we throw light in these two countries such as in New Zealand and Canada, commercial surrogacy has already been regarded as against the legislation due to the same reason such as business of body parts, but altruistic surrogacy because in this practice no illegal conduct arises. In these three powerful nations like Germany, Italy, and France, commercial surrogacy is not at all acceptable. Therefore, in order to control illegal use of practice India sought to pass law and make surrogacy arrangements protected and the rights of surrogate mother, child and the genetic parents ${ }^{21}$.

Only exchange of services helps in the commencement of surrogacy. If we observe medically each year there are number of members who are in a requirement of organ transplantation such as heart, kidney or lungs due to certain disorders in the Human Body. Although, life saving organs are not easily accessible in India as compared to surrogate babies on rent. We all must be satisfied that the surrogacy is completely different from the transplantation of body parts. In order to solve this problem India established a body known as Indian council of Medical Research which works in the various medical fields along with the modern technologies as per the decision of Ministry of Well-Being.

\section{iii. Speed breakers on the path of surrogacy}

India was the first country in the world who planned to pass law for commercial surrogacy because of the poor management in the surrogacy services. In order to control the commercial surrogacy the surrogacy regulation bill came into force in order to stop the use of commercial surrogacy in the year 2010 which was suggested by the Indian council of Medical Research the most effective body in the India. As per the Asian nation there was a complete report of the medical industry which suggests that there are around number of women who rent their wombs around Rupees 25,000 crores. As per the provision of Indian nation surrogacy purposes consist of certain issues in the path

\footnotetext{
${ }^{20}$ Regulation of surrogacy in India: whence forth now? Available at https:// www.ncbi.nlm.nih.gov.
}

${ }^{21}$ Surrogacy laws by Country available at https://en.m.wikipedia.org. related to law, moral duty and as well as financial requirements for the surrogate mother and also renting wombs on national and international scale. For the commencement of surrogacy there is a list of complete equipment which should be there such as genetic pool banks, superior services in health care centers, and complete protection to the surrogates throughout the process of surrogacy and proper reports to be registered with the ART Clinics and also made category of persons in which gay, sole or unmarried pairs can become parents through surrogacy, and no one will be questioned regarding their religion, cast, sex etc.

\section{Fresh indian medical visa regulation will limit surroga- cy $^{22}$}

India felt that surrogacy will be keep on going. In order to control the daily exploitation India passed fresh visa regulations which came into knowledge on 15 November, 2012 and on the basis of this current visa regulations foreigners need to operate on the current regulations and no one will be compromised from global country because law is equal for every country but we mostly hear such things in text. This visa regulations were made in order to stop the misuse of illegal practice and operate on the genuine basis if any person try to violate such visa regulations, they need to face penalties as per Indian regulations and can also lead to cancelation of visa. The main objective behind visa regulation was to obtain the consent from the citizens of international country with the help of embassies in the Indian nation or can take help from their respective country if such foreign citizens are interested in the process of surrogacy, they need to maintain the laws which are established by any country. This matter is not only concerned with the foreign citizen but it is a matter of concern for Indian surrogate as well. These visa regulations formalities should be completed of the Health centers of India and such ART Health centers will forward such documents of foreign citizens with the Indian Research known as Indian Council of Medical Research and the Indian Research Committee will also ensure that a proper lawful binding agreement with proper stamps of the commissioning parents must be there so that they do not neglect after the commissioning of surrogacy foreign citizens must inform once through confirmation certificate related to the way out plan of infant from India to some other international country and this condition is requisite and this certificate must ensure consent from the commissioning parents that will not intervene in the matter of surrogate after the process to ensure the safety and these all formalities are supervised under the ART health care centers. Foreigners need to send such authorization of certificates from the department of Indian Foreign Regional Registration and this department also investigates into all the checks and balances of the process of surrogacy. With the help of Such regulations the life of surrogate mother will be comfortable and free of issues.

\footnotetext{
${ }^{22}$ India clarifies stand on Surrogacy VISA Regulation available at blog. indiansurrogacylaw.com.
} 


\section{Medical visa regulations will match with existing indian and foreign regulation of countries of commissioning parents $^{23}$}

This regulation states that the conduct of commercial surrogacy is not at all acceptable in the United Kingdom but as per British provision it is considered legal and also concerned with the appropriate compensation to be provided to the surrogate mother and which cannot be compromised at any cost. If we compare US from UK then compensated surrogacy arrangements is major parts of the country is completely unregulated. As per Australian provision giving shelter to the practice of commercial surrogacy is strictly prohibited and also considered illegal to provide help to the commissioning parents and surrogates. As per the regulation followed in the New Zealand and Canada commercial surrogacy is not at all followed but only altruistic surrogacy can be practiced. If we take these three countries such as France, Italy and Germany, no form of surrogacy is permitted whether commercial or altruistic surrogacy and as per the provisions of these three countries only surrogate mother was considered to be the real mother of an infant. Only in India commercial surrogacy is regulated due to poverty aspects on a emerging scales. But as per the implementation of Indian Medical Visa Regulations foreigners need to maintain their visa regulations only then they can visit India for the purpose of surrogacy arrangements even their foreign countries do not permit them. Although commercial surrogacy is not appropriate but if it is conducted to build the family not for business purposes then it is not at all wrong. As per Indian country unattached foreign citizen, solo or gay couples by limiting surrogacy for foreign man and woman only who must have completed their marriage for up to a period of two years as per the Indian regulation. Due to such alterations in provisions no ART health centers, commissioning parents from India or foreign country matters will now cannot approach without registration and proper functioning will be conducted in India. It is provided that any children delivered through the modern assisted technologies who belong to foreign parents will not be granted Indian nationality and such persons will not be permitted to enter into the practice of surrogacy such as gay couples, sole persons and unmarried partners will be officially recognized in India.

\section{iv. Some recent matters}

a. In the matter of Baby Manji Yamada vs Union of India \& Anr. on 29, September, $2008^{24}$. One of the renowned matters of Japanese infant Manji who was born on 25 July, 2008 in India with the help of advanced technology (IVF) and Indian surrogate and the eggs were fertilized in Japan and sperms in Tokyo and when the embryo was placed for further process in Ahmedabad ART industry, then the issue arose up to the court premises. When this matter approach to the court the Japanese parents got separated from each other and no one is ready to accept such child. After the child was left alone her Japanese grandmother came in support of the baby and filed an appeal in the Supreme Court on the basis of the instructions posed by the Rajasthan High Court questioning who will going to handle the custody and how will his identity will come into knowledge. Her grandmother appealed to the Apex Court requesting to let us move to their respective country along with their passports and grandmother assured them that she will going to take care of such grandchild. After hearing the opinion of the grandmother, the central government was also coming in support of grandmother. After sometime Supreme Court made a decision dated 29 September, 2008, and as per their instruction of the Supreme Court the District Passport Office in Jaipur had decided to deliver an "Identity official document" related to the child on 1 November, 2008. When the official document came to the grandmother the Supreme court had permitted both the grandmother and her grandchild that she can go their respective country but still somewhere in the mind this question arises to related to the nationality of the infant.

b. In the matter of Omer Gher v. Yonatan on 12 October, 2008. The second matter is related with gay parents who lived in Israel but they came to India for the purpose of surrogacy and took help from Indian surrogate because the surrogacy services were so cheap in India as compared to their country and this matter aroused on 12 October, 2008. The name of the parents were Omer Gher and Yonatan who wanted to have a child in their life and that baby was delivered in Powai which was in Mumbai at Hiranandani Hospital and the doctors informed them that they were blessed with a male infant who was around $3.8 \mathrm{Kilo}^{25}$.

As per the knowledge Omer and Yonatan, were staying as husband and wife and their marriage has completed seven years after they decided to make family plans. But as per the Israel regulation it is stated that in Israel same sex relations are not acceptable so they decided to take help from India and in January 2008 they came to Mumbai and with the help of Indian surrogate they continued their live with a healthy infant and converted into 3 members. Once the Israel pair got their kid they went to their respective country on 17 November, $2008^{26}$.

c. In the third matter Jan Balaz v. Union of India (2008) two surrogate kids were involved named as Leonard and Nickolas. This matter took around 2 years where the German parents named as Jan Balaz and Susan Anna. Both of these fought for their child custody for a 2 year long lawful battle into the Supreme Court of India. Jan Balaz and Susan belong to Germany. This matter came into knowledge when it was constituted as per the jurisdiction of the Supreme court. These twin kids were delivered in the year January 2008 with the help of Indian. This birth process took in the state of Gujarat. Jan Balaz who was the father of these surrogate kids need to approach to the Gujarat High Court where the question arise who will going to be the parents of these 2 kids. Gujarat State High Court earlier declared as per the proof these 2 kids were born on the land of India with the help of Indian surrogate so

\footnotetext{
${ }^{23}$ Blog.indiansurrogacylaw.com

${ }^{24}$ Matter of Baby M, 109 NJ 396(NJ 1988).
}

${ }^{25}$ Available at nytimes.com
${ }^{26}$ Available at https://m.timesofindia.com 
these kids will going to belong to the Indian nation but their intended parents Jan Balaz and Susan had not accepted their opinion. In this matter Indian government also intervened in the matter and declared though these kids were born on the land of India but these kids were born through surrogacy so this proves the fact that such kids also belong to them as well because surrogacy is a practise where the not one but two parties were involved after hearing this the Supreme Court of India passed decision in the favour of German parents and those parents went to their country after hearing this verdict.

\section{Conclusion}

All these above stated matters deal with the commissioning of surrogacy but the issues involved in the matter is totally different but lastly, in these the conclusion was in the favor of surrogate babies and these matters are beneficial for the advancement of technologies and also encouraged surrogate mothers to provide help to the needful parents.
Discover a bigger Impact and Visibility of your article publication with

\section{Peertechz Publications}

Highlights

* Signatory publisher of ORCID

* Signatory Publisher of DORA (San Francisco Declaration on Research Assessment)

* Articles archived in worlds' renowned service providers such as Portico, CNKI, AGRIS, TDNet, Base (Bielefeld University Library), CrossRef, Scilit, J-Gate etc.

* Journals indexed in ICMJE, SHERPA/ROMEO, Google Scholar etc.

* OAI-PMH (Open Archives Initiative Protocol for Metadata Harvesting)

* Dedicated Editorial Board for every journal

* Accurate and rapid peer-review process

* Increased citations of published articles through promotions

* Reduced timeline for article publication

Submit your articles and experience a new surge in publication services (https://www.peertechz.com/submission).

Peertechz journals wishes everlasting success in your every endeavours.

Copyright: ( 2021 Chaudhary V. This is an open-access article distributed under the terms of the Creative Commons Attribution License, which permits unrestricted use, distribution, and reproduction in any medium, provided the original author and source are credited. 